\title{
MADRASAH PADA MASA ISLAM KLASIK: Analisis Historis atas Metode yang Digunakan
}

\author{
Hasaruddin \\ UIN Alauddin Makassar Jl. Sultan Alauddin No. 23 Makassar \\ E-mail: hasruddinsyarif@yahoo.com
}

\begin{abstract}
Abstrak: Lembaga pendidikan Islam yang paling utama pada era klasik ialah masjid. Namun demikian, karena tuntutan masyrakat muslim terhadap pendidikan semakin meningkat dan tuntutan kesejahteraan para guru juga semakin meningkat maka pendidikan yang pada awalnya berlangsung di masjid, dialaksanakan pula di madrasah. Lembaga pendidikan madarah adalah pengembangan dari masjid, menjadi masjid khan kemudian meningkat menjadi madrasah. Metode pembelajaran yang digunakan di madrasah pun telah mengalami perkembangan. Metode pembelajaran di madrasah yang meliputi al-samā', al-imlā', dan al-ijāzah tidak ditemukan dalam pembelajaran di masjid.

Abstract: The Institute of Islamic education is foremost on the classic era is the mosque. However, because of the demands of Muslim society to education has increased and the demands of the welfare of the teachers have also increased the education that was originally held in the mosque developing into education held at the madrasah. Therefore, madrasah educational institutions were the development of the mosque, the mosque khan then increased to madrasah. Learning methods used in the madrasah also experienced growth. The method of learning at the madrasah such as al-samä (dictation), and al-ijäzah (diploma) was not found in the learning in the mosque
\end{abstract}

Kata Kunci: madrasah, masa Islam klasik, metode pengajaran 


\section{PENDAHULUAN}

Madrasah merupakan pengembangan dari lembaga pendidikan yang sebelumnya dilakukan di masjid-masjid yang memberikan pengajaran secara halaqah.

Seiring dengan perkembangan dan kemajuan zaman maka madrasah lahir sebagai jawaban dari meningkatnya kebutuhan akan pendidikan khususnya dalam menimba ilmu pengetahuan. Metodologi yang digunakan di madrasah juga berbeda dengan yang diberikan di masjid-masjid sebelumnya. Metode pengajaran di madrasah lebih maju daripada pengajaran di masjid.

Kata metode sudah seringkali diungkapkan dan dikemukakan. Kata itu berasal dari dua kata yakni, meta dan hodos. Menurut M. Arifin, meta berarti melalui dan hodos berarti jalan atau cara. ${ }^{1}$ J.S Badudu dan Sutan Muhammad Zain menegaskan, metode ialah cara yang digunakan untuk melaksanakan sesuatu pekerjaan agar tercapai hasil yang baik sebagaimana yang diharapkan. ${ }^{2}$ Oleh karena itu, dapat disimpulkan, bahwa metode pendidikan adalah cara-cara yang harus dilalui atau digunakan dalam proses mendidik dan belajarmengajar. ${ }^{3}$

Metode pendidikan adalah salah satu aspek dalam kegiatan belajar mengajar, di mana usaha transformasi pengetahuan mengambil bentuk yang lebih efektif. Terkadang materi yang berbobot belumlah dapat berarti bilamana cara menyampaikannya kurang tepat. Untuk itulah ungkapan yang

\footnotetext{
h. 61 .

${ }^{1}$ M. Arifin, Ilmu Pendidikan Islam (cet. Ke-1; Jakarta: Bumi Aksara,1991),

2 J.S. Badudu dan Sutan Muhammad Zain, Kamus Umum Bahasa Indonesia (Jakarta: Integrafika, 1994), h. 45.

${ }^{3}$ M. Arifin, Hubungan Timbal Balik Pendidikan Agama di Lingkungan Sekolah dan Keluarga (Jakarta: Bulan Bintang, 1978), h. 67.
} 
sering kali dikemukakan dan amat dikenal ialah metode lebih penting daripada materi.

Ungkapan di atas tidak berarti materi pelajaran dikesampingkan sama sekali, tetapi lebih ditekankan agar para pengajar lebih aktif lagi dalam memperhatikan metode yang digunakan pada saat mengajar. Adapun fokus tulisan ini adalah apa yang melatarbelakangi didirikannya madrasah pada masa Islam klasik? Dan bagaimana metode pengajaran yang digunakan di dalamnya?

\section{LATAR BELAKANG MUNCULNYA MADRASAH}

Dalam perkembangannya, madrasah lebih dikenal sebagai tempat di mana para siswa menerima pengetahuan agama Islam secara sistematis. Oleh karena itu, pada pertengahan abad ke-5 hijriah berdirilah sebuah madrasah yang didirikan oleh Niẓām alMulk yang dikenal dengan Madrasah Niẓāmiyyah . Menurut Richard W. Bulliet, di daerah Nisapur telah ada lembaga pendidikan madrasah jauh sebelum didirikannya madrasah Niẓām al-Mulk. ${ }^{4}$

Al-Maqrizi, sebagaimana dikutip oleh Ahmad Syalabi menyatakan bahwa institusi sekolah atau madrasah pertama kali diperkenalkan pada akhir abad ke-4 hijriah oleh penduduk Nisabur, yaitu madrasah al-Baihaqiyyah. Madrasah ini merupakan institusi pertama yang berbentuk sekolah di dunia Islam. ${ }^{5}$

Dalam pandangan Makdisi, madrasah merupakan fase ketiga dalam garis lembaga pendidikan Islam, dengan urutan; masjid,

${ }^{4}$ Ia menegaskan bahwa di daerah Nisapur bahkan ada beberapa puluh madrasah, di antaranya adalah madrasah Miyam Dahiya, dan Madrasah Saidiyah. Richard W. Bulliety, The Partician of Nissapur: A Study in Medieval Islamic Social (Cambridge: Harvard University Press, 1972), h. 29.

${ }^{5}$ Ahmad Syalabi, Tārikh al-Tarbiyyah al-Islāmiyyah (Kairo: Dār al-Ittihạā al-‘Arabī, 1976), h. 127. 
masjid khan, ${ }^{6}$ kemudian madrasah. ${ }^{7}$ Madrasah merupakan jawaban yang tepat terhadap tantangan dan kebutuhan akan suatu lembaga pendidikan yang lebih profesional. Masjid dan masjid khan betapa pun besar peranannya, merupakan tempat ibadah sehingga sedikit sekali waktu untuk bisa belajar dengan tenang di tempat-tempat tersebut. Ketika masjid dan masjid khan dirasakan kurang representatif lagi untuk tujuan pendidikan Islam dan aktivitas pendidikan karena dianggap menganggu ketenangan beribadah, maka pendirian madrasah adalah solusi yang dianggap paling tepat untuk mengatasinya. Faktor eksternal yang juga berperan dalam pengembangan konsep baru ini menurut Nekosten- adalah kenyataan bahwa kemajuan ilmu pengetahuan telah melahirkan kelompok intelektual baru, tentunya memajukan dan mengembangkan lembaga pendidikan seperti madrasah merupakan usaha untuk menyediakan lahan baru bagi mereka. ${ }^{8}$ Secara lebih tegas dapat dikatakan bahwa latar belakang didirikannya madrasah adalah karena masjid-masjid telah dipenuhi dengan halaqah-halaqah, pengajian oleh para guru dan murid-murid yang semakin berdesakan. Sehingga menganggu orang yang bersembahyang dari satu segi, dan segi lainnya ialah karena pesatnya perkembangan ilmu pengetahuan setelah makin berkembangnya kegiatan penerjemahan buku-buku asing atau non Arab ke dalam bahasa Arab.

Adapun yang menjadikan madrasah ini lebih penting fungsi dan peranannya ialah karena kelengkapan ruangannya untuk belajar, yang dikenal dengan ruangan muhāẹarah atau ruangan

${ }^{6}$ Istilah khan dapat diartikan sebagai pemondokan (penginapan musafir) tetapi dalam hubungan ini istilah tersebut berarti asrama mahasiswa yang berasal dari desa-desa yang jauh yang pada umumnya belajar fikih.

${ }^{7}$ George Makdisi, The Rise of Colleges (Edinburgh: Edinburgh University Press, 1981), h. 27.

${ }^{8}$ Mehdi Nakosten, History of Islamic Origins of Western Education A.D 800-1350 with an Introduction to Medio Muslim Education (Balder: The University of Colorado Press, 1964), h. 45. 
diskusi beserta bangunan-bangunan yang berkaitan dengannya, serta pengamanan bagi murid-murid dan guru-gurunya. Selain itu, terdapat ruangan-ruangan lain yang dibangun untuk dapur, ruang makan, dan lain-lain. ${ }^{9}$ Sebenarnya, munculnya lembaga pendidikan formal dalam bentuk sekolah-sekolah dalam dunia Islam -selain faktor yang telah disebutkan di atas- merupakan pengembangan dari sistem pengajaran dan pendidikan yang telah berlangsung di masjid-masjid, yang sejak awal telah berkembang dan dilengkapi dengan sarana-sarana untuk memperlancar pendidikan dan pengajaran.

Dengan fasilitas yang ditawarkan oleh madrasah, menjadikan kehidupan siswa lebih terjamin daripada di masjid dan masjid khan. Karena disamping menyediakan asrama dan logistic, madrasah dengan wakafnya menyediakan seluruh kebutuhan pokok siswa dalam belajar. ${ }^{10}$ Dengan demikian semakin terlihat perbedaan antara madrasah dengan masjid khan, karena fungsi utama masjid khan tidak berbeda dengan masjidmasjid yang lain yaitu sebagai tempat ibadah, sedang fungsinya sebagai tempat pendidikan menempati posisi berikutnya. Sementara madrasah fungsi utamanya adalah lembaga pendidikan, walaupun di dalam kompleksnya dibangun masjid tapi kala itu bukanlah sebagai centra kegiatan.

Ada sesuatu yang menarik untuk didiskusikan dibalik fenomena madrasah ini, mengapa para pewakaf mengalihkan perhatian mereka kepada madrasah, bukan lagi kepada masjid? Mungkin ini erat kaitannya dengan sistem patronase terhadap masjid-masjid kala itu. Biasanya baik masjid Jami' maupun masjidmasjid non jamik sebagai rumah ibadah berada dalam yuridiksi para penguasa, dalam hal ini khalifah dan sultan. Dengan demikian, pembangunan, pengangkatan staf dan dukungan

\footnotetext{
${ }^{9}$ Ali al-Junbulati, Perbandingan Pendidikan Islam, terj. M. Arifin (Jakarta: Rineka Cipta, 1994), h. 30.

${ }^{10}$ Makdisi, The Rise of Colleges ..., h. 32.
} 
finansial bersumber dari agen pemerintah. Sedangkan madrasah bebas dari sistem kontrol seperti di atas. Sebagai lembaga pendidikan, kontrol atas kegiatannya sepenuhnya berada dalam tangan pemberi wakaf. ${ }^{11}$ Madrasah Niẓāmiyyah misalnya, yang dibangun pada pertengahan abad ke-5 hijrah adalah sebagai upaya Niẓām al-Mulk untuk menghindari campur tangan khalifah. Dengan demikian, ia bisa mengontrol madrasah semaksimal mungkin sesuai dengan kemauan dan tujuan politiknya. ${ }^{12}$ Dengan demikian, dapat dikatakan bahwa madrasah melambangkan keunikan dari sebuah lembaga pendidikan pribadi.

Dalam pembangunan madrasah, Niẓām al-Mulk menyediakan wakaf untuk membiayai para pengajar, seorang imam dan juga para siswa yang menerima beasiswa dan fasilitas asrama. Beasiswa untuk para siswa tersebut adalah bentuk perbedaan antara madrasah dan masjid akademik. Dengan demikian, madrasah lebih menarik bagi para siswa yang berasal dari keluarga kurang mampu, dan ini adalah penyebab dari disediakannya tempat tinggal bagi para ilmuwan dan para siswa kurang mampu. ${ }^{13}$

Patron lain juga mengikuti langkah-langkah Nizāam al-Mulk. Dalam ukuran kurikulum dan pengajaran, madrasah, tidak jauh berbeda dengan masjid akademi. Perbedaannya hanya kemandirian madrasah dari kontrol langsung otoritas keagamaan dan penyediaan beasiswa untuk para pelajar, dua hal yang tidak ditemui pada sistem pendidikan masjid di era sebelumnya. ${ }^{14}$

\footnotetext{
${ }^{11}$ Hasan Asy'ari, Menyingkap Zaman Keemasan Islam, Kajian atas Lembaga Pendidikan (Bandung: Mizan, 1994), h. 47.

${ }^{12}$ Makdisi, The Rise of Colleges..., h. 53.

${ }^{13}$ Charles Michael Stanton, Pendidikan Tinggi Dalam Islam,terj. H. Affandi dan Hasan Asy'ari (Jakarta: Logos Wacana Ilmu, 1994), h. 47.

${ }^{14}$ Ibid, h. 49.
} 
Beberapa tahun kemudian, khalifah al-Mustanshir mendirikan sebuah lembaga pendidikan tinggi yang terdiri atas beberapa bangunan yang kemudian diberi nama sesuai dengan nama pendirinya, yaitu Madrasah al-Mustanșiriyyah mencakup empat madrasah, masing-masing mewakili setiap mazhab yang empat, yang secara terpisah menjalankan pengajaran dan memiliki asrama bagi para pelajar dan para stafnya. Semua pelajar dan staf menerima gaji dari penghasilan wakaf yang disediakan oleh khalifah. Dengan dibangunnya Madrasah alMustanșiriyyah, satu transisi penting terjadi lagi dalam evolusi lembaga pendidikan Islam, yaitu lembaga-lembaga kecil dengan hanya seorang syaikh, di beberapa kota beralih menjadi lembagalembaga pendidikan yang lebih besar dan lebih kompleks. Madrasah-madrasah yang didukung oleh wakaf dalam jumlah besar pada saat itu cenderung mencakup lebih dari satu mazhab didalamnya. ${ }^{15}$

Pada masa Dinasti Ayyūbiyah, di Mesir para penguasa dan para pembesar lainnya berlomba-lomba mendirikan madrasah, di antaranya adalah Madrasah al-Nașiniyyah, Madrasah al-Saifiyyah dan Madrasah al-Faḍliyyah yang dibangun oleh Sultan al-Qādī alFāẹil, yang terkenal dengan nama Abd al-Rahīm bin 'Alī al-Bisānī. Dialah yang membangun berbagai perpustakaan pada setiap madrasah yang dilengkapi dengan beribu-ribu jilid buku, yang menunjukkan bukti bahwa perpustakaan berperan besar dalam pengembangan kebudayaan dan pendidikan. Begitupula Nūr alDīn Zankī di Damaskus mendirikan madrasah yang terkenal dengan nama Madrasah Nūriyyah Kubrāa, disamping berbagai madrasah lainnya. ${ }^{16}$

Dengan berdirinya madrasah-madrasah tersebut maka lengkaplah lembaga pendidikan Islam yang bersifat formal mulai

\footnotetext{
${ }^{15}$ Ibid., h. 52.

${ }^{16}$ Mahmud Yunus, Sejarah Pendidikan Islam (Jakarta: Hidakarya Agung, 1989), h. 76.
} 
dari tingkat dasar yaitu kuttāb sampai tingkat menengah dan atas. Lembaga-lembaga pendidikan formal tersebut belum memiliki kurikulum yang seragam artinya masih bervariasi antara madrasah yang satu dengan yang lainnya. Hal ini sangat bergantung kepada keahlian para gurunya. Pandangan mengenai pentingnya ilmu pengetahuan berhubungan dengan perhatian dari para pembesar sekaligus pendiri sekolah atau madrasah bersangkutan.

\section{METODE PENDIDIKAN FORMAL}

\section{Masjid (kelompok halaqah)}

Sebelum madrasah didirikan, masjid merupakan pusat segala aktivitas kaum muslimin, termasuk di dalamnya pendidikan yang dilaksanakan dalam bentuk halaqah. Meski tidak terstruktur, kelompok belajar yang disebut halaqah ini pada akhirnya berkembang menjadi lembaga formal. Pada mulanya seorang guru menjadi syaikh halaqah secara alami, dan statusnya ditentukan oleh pengikutnya sendiri. Pada tahap selanjutnya, dengan persiapan formal seorang syaikh halaqah dapat diangkat menjadi pengurus masjid. Pada akhirnya, syaikh halaqah berkembang menjadi penafsir yang menetapkan hukum sebagaimana termaktub dalam Alquran dan hadis. Pada tahap selanjutnya, para ulama secara khusus diangkat menjadi guru agama dan memimpin berbagai halaqah sehingga sejarah lembaga formal pendidikan tinggi berikutnya berawal pada terbentuknya berbagai halaqah lainnya di berbagai masjid. ${ }^{17}$ Satu halaqah mengambil tempat di satu sudut atau di seputar satu pilar dalam satu masjid, dan biasanya berlangsung pada waktu tertentu, utamanya pagi hari. halaqah biasanya diberi nama sesuai dengan nama syaikhnya, dan seorang syaikh biasanya tidak diperbolehkan memimpin lebih dari satu halaqah di satu masjid

${ }^{17}$ Ibid., h. 25. 
supaya tidak menimbulkan ketimpangan. Sering terjadi seorang syaikh berusaha mewariskan jabatannya kepada anak-cucu atau murid kesayangannya. Catatan sejarah juga membuktikan bahwa kepemimpinan di berbagai halaqah memang diwariskan dari seorang ayah kepada anaknya untuk beberapa generasi. ${ }^{18}$

Jabatan lain dari sebuah masjid yang memiliki halaqah selain syaikh- adalah imam yang ditugaskan memimpin salat jamaah dan menyampaikan ceramah pada tiap Jumat. Dalam beberapa kasus syaikh atau mudarris melaksanakan fungsinya sebagai pemimpin keagamaan (imām) di samping tugasnya sebagai tenaga pengajar dan administrator dari proses pendidikan. Jika keuangan memungkinkan, masjid dapat menambah stafnya dengan mempekerjakan seorang asisten guru (nā'ib), juru ulang ( $\left.m u^{\prime} \hat{i} d\right)$ dan seorang tutor (mufíd) Na'ib bertugas menggantikan syaikh atau mudarris ketika syaikh sedang sibuk. $M u^{\prime}$ îd dipercayakan untuk mengulangi ceramah mudarris kepada murid yang tidak memahaminya atau tidak hadir pada pertemuan tertentu. Mufìd membantu murid-murid yang lebih muda atau pemula, tetapi belum dianggap mampu mengulang ceramah mudarris seperti halnya $m u{ }^{\prime} \overline{1} d^{19}$

Masjid sebagai tempat menimba ilmu, menerima murid terdaftar maupun sekedar pengunjung untuk bergabung dalam halaqah. Pendidikan sangat tergantung pada murid dan keseriusannya dalam membaca sumber-sumber tambahannya agar dapat memahami ceramah dan uraian Syaikhnya dengan lebih baik lagi. Diskusi dan pandangan-pandangan baru didorong perkembangannya di dalam rangka menggali berbagai ajaran Islam.

Salah satu diantara ciri-ciri utama kurun waktu tersebut adalah kemampuan untuk menghafal. Ketika itu terdapat banyak

${ }^{18}$ Makdisi, The Rise of Collage..., h. 170.

${ }^{19}$ Stanton, Pendidikan Tinggi..., h. 41. 
mudarris (ahli hadis) yang dapat membaca ulang sebuah hadist tanpa kesalahan samasekali setelah hanya mendengar sekali saja. Hal ini mendorong lahirnya suatu metode baru, dimana hafalan merupakan bagian terbesar dalam latihan jiwa dan pembentukan kepribadian pada anak didik. ${ }^{20}$

Metode lain dari cara pengajaran pada saat itu adalah guru menyampaikan pelajarannya dengan mengucapkan frasa-frasa atau kalimat-kalimatnya satu persatu. Seorang asisten pengajar mengucapkan kembali keterangan yang telah disampaikan oleh seorang guru atau Syaikh dengan suara keras, sehingga dapat didengar dan dicatat secara lengkap oleh para siswa. Setelah itu sang guru atau syaikh memulai berdiskusi dengan siswa yang duduk didekatnya, dan akhirnya lingkaran diskusipun berkembang. Kadang-kadang guru juga berjalan di belakang para siswa dan ikut serta mendengarkan dan menyimak diskusi-diskusi mereka. Nilai yang diberikan oleh seorang guru ditentukan dengan ukuran seberapa jauh semua siswanya dapat mengikuti pelajarannya dengan baik. ${ }^{21}$

Setelah diskusi dan pelajaran selesai, para siswa untuk sementara waktu tetap bersama gurunya, dan mencoba mengambil manfaat dari kebersamaannya itu, sambil mencari inspirasi dari kehidupan sahabat yang memperoleh banyak ilmu pengetahuan hanya dengan berada bersama-sama Rasulullah saw. ${ }^{22}$

\section{Madrasah}

Munculnya lembaga pendidikan berupa madrasah dalam dunia Islam merupakan pengembangan dari sistem pengajaran dan pendidikan yang telah berlangsung di masjid-masjid, yang

\footnotetext{
${ }^{20}$ Hamid Hasan Bilgrami dan Sayyid Ali Ashraf, Konsep Universitas Islam, terj. Machnun Husein (Yogyakarta: Tiara Wacana, 1989), h. 33.

${ }^{21}$ Ibid.

${ }^{22}$ Ibid., h. 34.
} 
sejak awal telah berkembang dan dilengkapi dengan berbagai sarana untuk memperlancar pendidikan dan pengajaran di dalamnya.

Lembaga-lembaga pendidikan formal termasuk didalamnya madrasah pada saat itu -sebagaimana dikatakan di atas- belum mempunyai kurikulum yang seragam, tetapi masih bervariasi antara madrasah satu dengan lainnya. Hali ini tergantung kepada keahlian guru-gurunya, pandangan tentang kepentingan suatu disiplin ilmu, dan berhubungan pula dengan perhatian dari pembesar pendiri sekolah-sekolah atau madrasah yang bersangkutan. ${ }^{23}$

Ilmu-ilmu agama mendominasi kurikulum lembaga pendidikan madrasah, dan Alquran berada pada porosnya. Disiplin-disiplin ilmu yang lain sebagai penunjang untuk memahami dan menjelaskan makna Alquran tumbuh sebagai bagian inti dari pengajaran, dalam hal ini tafsir dan hadis. Tantangan utama dalam studi hadist adalah keharusan menghafal secara literal ratusan hadis. Madrasah sebagai lembaga pendidikan yang paling utama tetap memanfaatkan metode pengajaran yang telah berkembang di masjid. Metode ini melibatkan penyalinan manuskrip, menghafal dan keterlibatan dalam debat. ${ }^{24}$ Sebagai persiapan untuk belajar ilmu-ilmu agama termasuk di dalamnya ilmu fikih, seseorang harus mempelajari bahasa Arab yang mencakup gramatika dan komposisi serta pengenalan dasar-dasar prosa dan puisi. Studi pendahuluan tersebut dapat ditempuh dengan cara tutor pribadi atau dengan menghadiri halaqah seorang ahli bahasa Arab.

Fikih mendapat tempat tersendiri sebagai satu bidang kajian khusus dalam mazhab tertentu di mana ilmu-ilmu agama yang

\footnotetext{
${ }^{23}$ Zuhairini dkk, Sejarah Pendidikan Islam (Jakarta: Bumi Aksara, 1992), h. 102

${ }^{24}$ Stanton, Pendidikan Tinggi..., h. 65.
} 
lain berfungsi sebagai prasyarat. ${ }^{25}$ Di madrasah Niẓāmiyyah misalnya, berdasarkan piagam wakafnya dikhususkan untuk pengajaran mazhab Syafi'i, dan mazhab Abu Hanifah yang dibangun pada waktu yang sama di Bagdad dibangun khusus untuk mazhab Abu Hanifah. Namun tidak demikian halnya dengan madrasah al-Mustanshiriyah yang dibangun belakangan. Pada madrasah yang disebutkan terakhir ini diajarkan empat mazhab yang masing-masing mendapat fasilitas yang sama. ${ }^{26}$

Di madrasah pada umumnya, studi fikih diuraikan oleh seorang syaikh dalam satu silabus yang disebut ta'liqah. Ta'liqah ini disusun oleh masing-masing tenaga pengajar berdasarkan catatan-catatan perkuliahannya selagi menjadi mahasiswa, yakni bacaannya dan kesimpulan pribadinya tentang topik terkait. Ta'liqah mengandung rincian materi pelajaran, dan bisa membutuhkan waktu lebih kurang empat tahun untuk menyampaikannya dalam perkuliahan. Para pelajar menyalin ta'liqah dalam proses dikte, dan dalam banyak kasus mereka betul-betul hanya menyalin dengan sedikit perubahan.

Menurut Muniruddin Ahmed, ada tiga metode pendidikan yang dikembangkan di madrasah pada masa pendidikan Islam klasik, yaitu; al-samā', al-imlā', dan al-ijāzah ${ }^{27}$

\section{al-Samā'}

Secara literal arti al-samā' adalah mendengar, tetapi dalam konteks pendidikan istilah ini berimplikasi lebih luas. Pada prakteknya, dalam metode al-samā' ini dikenal tiga macam cara, yaitu (1) pengajaran secara langsung, di mana seorang guru membacakan sendiri pelajarannya dari hafalannya di hadapan para pelajar; (2) pelajar membacakan langsung pelajaran dari

\footnotetext{
${ }^{25}$ Makdisi, The Rise of Colleges..., h. 111-112.

${ }^{26}$ Asy'ari, Menyingkap Zaman Keemasan..., h. 64.

${ }^{27}$ Muniruddin Ahmed, Muslim Education and the Scholars' Social Statusu up to the $5^{\text {th }}$ Century Muslim (11 tahun, Century Christian Era in the Light of Tarikh Bagdad) (Verlag: Der Islam Zurich, 1968), h. 93.
} 
buku pengajar atau salinannya ataupun dari hasil hafalannya. Cara ini sama dengan model presentasi; dan (3) mendengarkan pelajaran yang disampaikan seorang pelajar kepada pengajar. Biasanya salah seorang pelajar dinominasikan oleh pengajar atau dipilih oleh para pelajar yang lain untuk mempresentasikan pelajaran atas nama seluruh pelajar yang laina. Cara seperti ini juga dikenal dengan istilah presentasi sebagaimana dikemukakan di atas. ${ }^{28}$

Metode presentasi amat dikenal di kalangan pelajar kala itu. Namun demikian, ada beberapa catatan yang mesti dipertimbangkan di dalam mengaplikasikan metode tersebut. Dalam hal ini, pengajar memperhatikan secara utuh apa yang dibaca oleh siswanya.

\section{al-Imlä'}

Metode kedua dalam transmisi pengetahuan adalah dengan cara al-imlā' (dikte). Metode ini selalu digunakan pada hampir setiap institusi pendidikan Islam klasik. Biasanya para pengajar mendiktekan pelajaran dari buku, namun tidak jarang pula dari mereka yang langsung mendiktekan dari hafalannya.

Untuk mendiktekan suatu pelajaran dalam institusi yang dihadiri oleh siswa, biasanya para pengajar dibantu oleh mereka yang bertugas mendiktekan pelajaran, yang disebut al-mustamli', tetapi juga $m u^{\prime} \bar{d} d$ yang bertugas mengulangi bacaan mustamli' dengan suara keras.

Untuk menjadi seorang mustamli' diperlukan kualifikasi khusus, yaitu yang mempunyai suara keras dan mengerti apa yang akan didiktekan. Selain itu, ia perlu memiliki pengetahuan yang baik tentang bahasa, dan yang terakhir ia harus memiliki sifat penyabar sehingga tidak mudah kehilangan kendali

${ }^{28}$ Ibid., h. 95. 
bilamana pelajar yang lain memintanya untuk mengulangi pelajaran untuk didiktekan.

\section{Al-Ijāzah}

Bentuk ketiga dari transformasi pengetahuan dikenal dengan nama al-ijāzah, yaitu seorang pengajar memberikan lisensi mengajar kepada seseorang peserta didik atas nama pengajar tersebut. Metode ini secara spesifik berlaku pada pengajaran hadis.

Selain dari ketiga metode pengajaran tersebut di atas, George Makdisi menambahkan bahwa Mużākarah (instructive conversation and memory contact) juga termasuk dalam metode belajar pada saat itu. ${ }^{29}$

Mużākarah adalah metode mengajar dengan cara memperlihatkan hasil hafalan di hadapan para pelajar. Metode ini memiliki fungsi ganda; pertama, Mużākarah sebagai alat untuk belajar dan menghafal materi-materi pelajaran yang diharapkan dapat menyegarkan hafalan para pelajar kedua, Mużākarah juga digunakan sebagai tes terhadap pengetahuan pelajar yang ingin menyelesaikan studinya. Metode ini biasanya ditentukan dalam kurikulum sastra terutama bahasa Arab.

Metode lainnya yang juga berkembang dalam pendidikan Islam klasik adalah munāzarah atau debat. Terlepas dari kontroversi tentang akar tradisi munāzarah, sebagian menyebutkannya sebagai adopsi umat Islam dari umat lain, sementara sebagian lain juga menetapkan bahwa ia merupakan praktek yang sepenuhnya produk tradisi. ${ }^{30}$ Yang jelas ia menjadi suatu fenomena menarik dalam sejarah intelektual muslim. Sejarah banyak mencatat tentang cendekiawan muslim yang piawai dalam berdebat, seperti; Imam Syafi'i, dua pakar linguistik

\footnotetext{
${ }^{29}$ George Makdisi, The Rise of Humanism in Classical Islam and the Christian West (Edinburgh: EUP, 1990), h. 208

${ }^{30}$ Makdisi, The Rise of Colleges..., h. 245.
} 
yakni Sibawayh dan al-Kisni, ${ }^{31}$ dan lain lain. Perbedaan pendapat dan segala argumentasinya akan terungkap dalam munāzarah. Seorang pakar dituntut tidak hanya memahami satu pendapat, tidak pula cukup dengan mengetahui alasan pendukungnya, tetapi juga dituntut dapat mengembangkan argumentasi baru untuk mempertahankan ide dan pendapatnya.

Ada beberapa fungsi yang didapat dari metode ini. Pada level teori, munāzarah berfungsi sebagai teknik pencarian kebenaran. Beberapa ulama' seperti al-Kātib dan al-Ghazālī menganggap pencarian kebenaran inilah sebagai alasan utama diselenggarakannya munāzarah. Al-Asy'ari menyatakan munāzarah adalah salah satu jawaban terhadap perintah al-Amr bi al-ma'rūf wa al-nahy 'an al-munkar. ${ }^{32}$ Pada level yang lebih praktis munāzarah berfungsi sebagai sarana pengujian kemampuan. Di sini, kemahasiswaan seorang mahasiswa atau keilmiahan seorang ilmuwan akan terlihat dan dapat dibandingkan dengan lawannya. Seseorang akan diakui sebagai sarjana bila ia telah mampu melakukan munāzarah secara baik pada bidangnya dengan para ilmuwan lain. Hasil suatu munāzarah seringkali dijadikan sebagai tolak ukur kelayakan seseorang untuk satu posisi tertentu, seperti mufti dan guru atau dosen, sebagaimana yang dialami al-Gazālī pada masa pemerintahan Niẓām al-Mulk. ${ }^{33}$

Ketika seorang mahasiswa telah merasa siap dalam bidang studi tertentu ia maju untuk menjalani ujian lisan. Jika penampilannya memenuhi standar yang ditentukan oleh mudarris atau syaikhnya, ia akan menerima sebuah ijāzah dalam bentuk surat keterangan yang menyatakan kelayakannya untuk

\footnotetext{
${ }^{31}$ Ibid., h. 211. h. 49 .

${ }^{32}$ Al-Ghazālī, Ihyā' 'Ulūm al-Dīn (Kairo: Mușțafā al-Bāb al-Ḥalabī, 1959),

${ }^{33} \mathrm{Ibnu}$ al-Imad, Syajarat al-Żahab fí Akhbār 'an Żahab (Kairo: Maṭba'at alQudsi, 1931), h. 11-12.
} 
mengajar satu bidang studi tertentu. Jika ia seorang mahasiswa yang mendalami bidang fikih, ijāzah yang diterimanya akan menyatakan kemampuannya mengeluarkan fatwa. Mereka yang sudah memiliki ijāzah dapat minta izin kepada syaikhnya untuk keluar dan mencoba membangun karirnya sendiri secara profesional di lembaga-lembaga serupa atau menjadi pegawai pemerintah sebagai mufti dan sebagainya.

Dari keseluruhan metode belajar yang dikembangkan, metode hafalan tampaknya yang terpenting dan amat dominan. ${ }^{34}$ Hal ini disebabkan oleh adanya penekanan pada aspek penguasaan kognitif proses belajar-mengajar, . meskipun selain metode hafalan metode lain juga tetap digunakan.

\section{PENUTUP}

Dari uraian yang telah dikemukakan dapat ditarik kesimpulan bahwa:

- Berdirinya lembaga pendidikan madrasah adalah sebagai bentuk pengembangan dari sistem pendidikan dan pengajaran yang telah berlangsung di masjid-masjid. Hal ini dimaksudkan untuk memberikan jawaban terhadap kebutuhan masyarakat yang cukup mendesak. Masjid-masjid pada saat itu dianggap kurang kondusif lagi untuk tujuan pendidikan karena selain dianggap menganggu ketenangan beribadah, juga masjid telah dipenuhi oleh halaqah yang semakin berdesakan.

- Metode pendidikan halaqah di masjid-sebelum berdirinya madrasah- adalah menggunakan metode ceramah yang dilakukan oleh seorang syaikh kepada murid-muridnya dengan mengandalkan kemampuan hafalan, yakni dengan mengucapkan frasa-frasa atau kalimat-kalimat satu demi

${ }^{34}$ Bayard Doodge, Muslim Education in Medieval Times (Washington: The Middle Institute, 1962), h. 10. 
satu, setelah itu barulah dibuka forum diskusi dan tanya jawab.

- Sebagai lembaga pendidikan formal yang muncul belakangan, madrasah juga menggunakan metode pendidikan yang diterapkan di berbagai halaqah, tetapi metode pendidikan madrasah lebih variatif dan lebih berkembang karena di samping seorang mudarris dalam menyampaikan materi perkuliahan dengan cara al-sama', al-imla', dan al-ijāzah juga dilakukannya dengan cara Mużākarah dan munāzarah, yang kesemuanya ini dapat membangkitkan semangat dan gairah bagi para siswa untuk berkompetisi di dalam belajar.

\section{DAFTAR PUSTAKA}

Ahmed, Muniruddin, Muslim Education and The Scholars Social Status Up to The $5^{\text {th }}$ Century Muslim $11^{\text {th }}$ Century Christian Era in The Light of Tarikh Bagdad, Verlag: Der Islam Zurich, 1968.

Arifin, M., Ilmu Pendidikan Islam. Jakarta: Bumi Aksara, 1991.

Arifin, M., Hubungan Timbal Balik Pendidikan Agama di Lingkungan Sekolah dan Keluarga, Jakarta: Bulan Bintang, 1978.

Asy'ari, Hasan, Menyingkap Zaman Keemasan Islam: Kajian atas Lembaga Pendidikan, Bandung: Mizan, 1994.

Badudu, J.S., dan Sutan Muhammad Zain, Kamus Umum Bahasa Indonesia. Jakarta: Integrafika, 1994.

Bayard, Dodge, Muslim Education in Medieval Times, Washington: The Middle Institute, 1962.

Bilgami, Hasan Hamid dan Sayyid Ali Ashraf, Konsep Universitas Islam, terj. Machnun Husein, Yogyakarta: Tiara Wacarna, 1989.

Bulliety, Richard W., The Partician of Nissapur: A Study in Medieval Islamic Social, Cambridge: Harvard University Press, 1972.

Gazālī, al-, Ihyā 'Ulūm al-Dīn, Kairo: Muștafāà al-Bābī al-Halabī, 1959.

Hasan, Hamid Bilgrami dan Sayyid Ali Ashraf, Konsep Universalitas Islam.

Terjemahan Machnun Husein, Yogyakarta: Tiara Wacana, 1989. 
Ibn al-Imad, Syajarat al-Żahab fī Akhbār 'an Żahab, Kairo: Maṭba'ah alQuds, 1931.

Junbulati, Ali al-, Perbandingan Pendidikan Islam, terj. M. Arifin, Jakarta: Rineka Cipta, 1994.

Makdisi, George, The Rise of Colleges., Edinburgh: Edinburgh University Press, 1981.

Makdisi, George, The Rise of Humanism in Classical Islam and the Christian West. Edinburgh: EUP, 1990.

Nakosten, Mehdi, History of Islamic Origins of Western Education A.D. 800-1350 with Introducation to Medio Muslim Education, Barder: The University of Colorado Press, 1964.

Stanton, Charles Michel, Pendidikan Tinggi dalam Islam, terj. Affandi dan Hasan Asy'ari. Jakarta: Logos Wacana Ilmu, 1994.

Syalabi, Ahmad, Tārikh al-Tarbiyyah al-Islāmiyyah. Kairo: Dār al-Ittihāa al-'Arabī, 1976.

Yunus, Mahmud, Sejarah Pendidikan Islam, Jakarta: Hidakarya Agung, 1989.

Zuhairini, dkk., Sejarah Pendidikan Islam, Jakarta: Bumi Aksara, 1992. 